\title{
ENDOWMENT AND JUSTICE: FROM TEXTUALISM TO SOCIOLOGICAL JURISPRUDENCE
}

\author{
JM. Muslimin \\ Syarif Hidayatullah State Islamic University (UIN) Jakarta \\ pisbar2000@yahoo.com / jm.muslimin@uinjkt.ac.id
}

\begin{abstract}
This paper aims at focusing the analysis on a practical reinterpretation of Qur'an and Hadith texts on waqf (religious endowment).

Qur'an and Hadith are the most important sources of norms for Islamic society. Therefore this article tries first to refer to the scriptures. Then, empirically proves that understanding Qur' an and Hadith in order to extract its essence as moral and normative guidelines (as in the case of endowment) works in various methods. One of them is a sociological jurisprudence.

This research finds that the text of Qur'an and Hadith on waqf has been interpreted beyond its textuality. That is due and for the sake of justice to achieve social benefit. The interpretation is legalized by the governmental decree as well as widely practiced by Indonesian Muslim society.

Thus, the text has been understood and translated wider. Reading the text through sociological jurisprudence implies to read the text in multi-stages: text, reader, author (revealer), and last but not the least social impact and surrounding (utilities).
\end{abstract}

Keywords: istibdal, waqf, justice, public interest, sociological jurisprudence

\section{Introduction}

\section{Waqf : Text and Teachings}

Amid the problems faced by Muslim community and the demand for people's welfare and economic interests recently, endowment becomes very strategic. Besides, it is one of the teaching aspects of the Islamic law which has a spiritual dimension, it is also the teachings that emphasize economic welfare not merely based on the spiritual aspect (Kemenag RI, 2008:1).

The word waqf derives from the Arabic in the form of mașdar (verbal noun) of waqafa - yaqifu, meaning al-habs (holding) or al-man'u (impeding), whereas the intended word of waqf is ism maf'ull, namely mawqüf (something made as waqf)(Mandzur, 1996:359).

The Muslim jurists differ on the meaning of waqf in the Islamic law. For the scholars of Malikite schools of law, the meaning of waqf is providing benefit of an article within unlimited time (eternal/ta'bid). The scholars of Hanafite schools of law argue that waqf is the benefit which is not ta'bid because it is not requisite of waqf. So it is possible to be managed li ghair ta'bìd (temporary), and on another occasion they call it as wealth whose yield and benefit are given for alms. While the Shafi'ite scholars define that waqf is to hold a capital then distribute its benefit to the community. Their views are different from the Hanbalite scholars who define waqf is to hold (a capital) whose profit to be used for religious services and good deed (Zuhaily, 1996:7-10).

As for contemporary legists, the meaning of waqf is not so much different from what has been mentioned by Wahbah Zuhaily. For example, Abu Zahra (1973) argues that waqf is to prevent legal action towards property by managing it in order to yield benefit to be distributed for virtues (Zahra, 1971:5). While Azhar Bashir (1994) maintains that waqf is holding property whose benefit can be taken without being vanished at once and for lawful utility and is intended to obtain Allah's consent(Basyir, 1987:15). Similarly, Muhammad 
Abdul Azhim argues that waqf aims at holding a capital so that its profit can be distributed for obtaining Allah's approval (Jamal, 2006:9-10).

Because waqf is not mentioned in any clear text or certain detailed Qur'anic verses especially on waqf, but it exists in the position of legally human understanding, derived from common text of scripture (ijtihādi) domain, and not solely based on scriptural dogmatism (ta'abbudi). Most of waqf laws are drawn through ijtihādī method like analogy (qiyās),public interest ( mașlahah) etc. Majority of Muslim scholars agree to relate waqf practices utilized for people's welfare with the term 'social endowment' (sadaqah jāriyah). In its development, the management of waqf keeps changing even experiences debate trend among Muslim scholars. One of the debates is on exchange of waqf object or it is often called istibdāl or $i b d \bar{a} l$ (exchange, substitution) (Hasan, 2009:3).

\section{Method}

This research is qualitative. The text of scripture is used as a source of meaning. Logical interpretation as well as sociological practice are the key to getting the data of empirical practice. the writer read the text in multi-stages: text, reader, author (revealer), and last but not the least social impact and surrounding (utilities).

\section{Discussion and Result}

\section{The Extension of Meaning and Logical Reasoning Model}

Muhammad Bakri ibn Ibrahim puts forward his opinion on endowment polemic that it is indeed a continuing qiy $\bar{a}$ s from money endowment as explained before that there is no verse of the Qur'ān which directly deals with the arrangement of endowment in al- Qur'ān. This matter, according to him, happens because it has similarity in the context of its benefits. That is due to some opinions of scholars that everything related with the endowment must have values, clear and owned totally by a wäqif (who gives endowment) and can be transferred to the endowment receiver (näzir) (Ibrahim, 2008:3).

Moreover, some of the scholars of Hanafite school of law even extend the scope of the meaning of wakaf (endowment) to allow dinar money endowment, for instance, or dirham based on the sociological jurisprudence perspective (istihsān bi al-'urf) (al-Azhar, 2011:238).

In the KHI (Kompilasi Hukum Islam or Islamic Law Compilation) chapter 16 on endowment is justified by the qiyass. A drastic effort of this law only to respond to the social need as a main goal of the endowment. For waqf there has been managed a variety of properties that can be categorized as moving objects which had not been known in the past, as a legal solution for contemporary model of transaction (Wahid :7).

Abu Fadl Muhsin maintains that waqf actually is not something categorized as ta'abbudi (devoutness), but as a result of ijtihäd of scholars of fiqh, responding to the development of shari'ah economy transaction which appears more progressive. Through the approach of qiyās (analogical deduction), the stock is decided as something that can be ruled with an object or non-object, which has to posses the same function, utility, even danger or the similarity of 'illat (cause) so that it can be categorized as endowment object which fulfils the requisites (Ibrahim, 2014:232).

Yusuf al-Qaradhawi maintains that ijtihād in the present time has to be synchronized with the social reality that prevails amid the community. Therefore, it is the responsibility of contemporary scholars to keep their $i j t i h \bar{a} d$, including the use of the qiyās methodology to see and understand the condition and situation of their society (Kesign, 2011:14).

Therefore, the execution of waqf is carried out by the established individuals in the field of economy. It is just like the proposition of the mentioned Prophet Muhammad's Hadith, who at that time was asked by Umar Ibnu Khattab on the land he owned in the 
region of Khaibar. This case indicates very clearly that Islam provides a concept of sustained welfare (Bukhari, 1991:285). In another story, it is mentioned that when the Prophet Muhammad died, he only left his yard as șadaqah (alms). This is what Muslim scholars consider as the legality of waqf execution for the social benefit and justice (Bukhari :293) It can be considered as a just endowment if the act and execution of charity will bring endless and broad social benefit. It is unjust, if the endowment can only bring about very limited social benefit.

Al-Shatibi $(1338 \mathrm{H})$ also clarifies that the naș of al-Qur'ān and Hadīth will not cause any harm to mankind. However, human knowledge which is very little brings about some mistakes in understanding these scriptures (nușuss). That is why Muslims are highly encouraged to study Islamic law as well as possible so that they are not mistaken in making an urgent decision, let alone leaving a great effect for the community in general (Al-Shatibi, 1997:245).

\section{Defining Islamic Justice in the Context of Endowment: From Text to Context}

The ultimate goal of law (including Islamic law) is justice. Within the justice, could be found social benefit. Therefore, all efforts related to the law must absolutely be directed to find a legal system that is most suitable and in accordance with the principle of justice. The law must be closely intertwined with justice. The law only becomes law when it meets the principles of justice. (Huijbers, 1995: 70).

Justice is closely related to the distribution of rights and obligations, a fundamental right as a divine gift in accordance with its basic rights. That is, the right of a person at birth and inviolable. Justice is one of the goals throughout the course of the history of legal philosophy.

The just nature is considered a constitutive part of the law. It is because law is seen as part of the ethical task of man in this world: the man is obliged to form a good life together by arranging it fairly. In other words, the human consciousness that arises from the conscience of the sacred duty of the spontaneous mission of justice is the reason why justice becomes the constitutive element of the law. In practical cases, it can be summarized as follows:

1. The government of any country always defends actions by showing real justice in it (some of the actions are artificial. But others are genuine).

2. Laws that do not comply with the principles of justice are often regarded as obsolete and invalid laws.

Justice is about to be steady, to be given to anyone according to the growth and development of society and the demands of the times. The correlation between philosophy, law and justice is very closed. Because there is a strong connection between the wisdom, norms and balance of rights and duties.

The concept of justice, even the concept of certainty and truth will always evolve, and therefore justice will evolve. Justice must be able to perform circular interaction with the development of other sciences, including theology, ideology, and technology. Justice is then linked to the institution and the human life and local activities. In the context of endowment, as far as the social benefit is maintained, the endowment can be performed in any forms: endowment of estate, endowment of money or changing the materials in order to spread a broader benefit (istibdal waqf), etc.

The change of the concept of justice over time is more prevalent on the operational plane, whereas its nature and essence are always static and testable: social benefit. From the concept of change and by adhering to the concept of "rights" then developed differentiation type of justice in the context of social endowment. 


\section{State Regulation, Social Benefit and Social Consensus}

Istibdāl waqf occurs in many cities. Some cases found in Jakarta. While others are in Tangerang, Cilegon, Subang, Aceh, Bali and Pontianak. It can be concluded from those cases, that istibdāl brought wider benefit about (Fahruroji, 2015:100-199).

There are some relevant State Regulations concerning waqf: Peraturan Pemerintah (PP), number 28, 1997; Undang-Undang Republik Indonesia Nomor 41 Tahun 1974 and its technical regulatory Peraturan Pemerintah (PP), Nomor 42 Tahun 2006, Regulation on Waqf of Indonesian Waqf Board (Badan Wakaf Indonesia, BWI), Number 1, 2008 (Abdurrahman, 2008).

On the essence of waqf article 1, PP Number 28, 1977 states: waqf is individual or corporate act with intention to donate his wealth in the form of estate and institutionalize this act eternally for the sake of 'ibādah in accordance to Islamic teaching. The State Regulation states also that the waqf property must be protected. It is not allowed to be sold, inherited, given or to treat it by any other means causing legal change of property ownership (UU Wakaf, 40).

In the context of istibdāl waqf, PP Number 42, 2006 declares that the changing of legal status of waqf (from eternal act to temporal one) is prohibited without prior permit from the Minister of Religious Affairs based on the consideration of Badan Wakaf Indonesia (BWI) (UU Wakaf, 41).

The written permit from the Minister can be awarded the following considerations: a. The changing legal status of waqf property happens due to necessary need on the bases of general planning of public space (Rencana Umum Tata Ruang, RUTR). The changing should be in accordance to the valid rules and sharia; $b$. The waqf property can not be used in line with waqf goal and its intention of declaration (ikrar wakaf); or c. The changing status occurs due to direct and immediate religious need (UU Wakaf, 41).

Careful and prudent comparative analyses between the debate on istibdāl in the Islamic law and articles of state regulation (PP 42, 2006) conclude that the regulation tries to accommodate legal ideas of Islamic law. The ideas of debate in the Islamic law contradict each other. Hence the method of reconciliation between state regulation and Islamic values lies on the bases of takhayyur, talfiq, tarjīh and siyassah shar'iyyah. It is eclectical way to select, compare and conclude with the purpose of fitting and choosing the parallel and proper ideas of text exegesis. Thus, social need and empirical considerations are the main frame of thought and dominant reference (Bowen, 2003).

By doing such a method, in the case of istibdāl, fiqh has been transformed: from irrational formality and irrational substance to rational formality and substance. In turn, this transformation brings Islamic legal values to be workable. The values are extracted, institutionalized, concluded and ready to be applied (Friedman, 1975: W Friedman, 1953: Hart, 1972).

In other words it can be stated that in the context of istibdāl waqf the legal interpretation of Qur'ān and Hadìth is done on the bases of sociological framework.

\section{Conclusion}

The Qur'ānic text on waqf is too general. The textuality of Hadīth which emphasizes the eternality of mauqu$f$ is transformed to be contextual: the main spirit is kept, the lateral message is left. It is indeed nothing is immutable. No single text has homogenous meaning (Hanafi, 2003: Cormick, 1978: McLeod, 1996).

To summarize, the text interacts with the readers. The readers make an effort to find social conformity between the text, its message and social necessity. Finding the innermessage could only be done by looking and examining social need. Through such a way, the public interest is defined, the improved prosperity is found. Istibdāl waqf is inevitably real 
need. The meeting point between state regulation and improved-selected interpretation and understanding of Qur'ān and Hadīth creates social consensus.

Further study on the social endowment should be conducted. The next study may focus to the comparative endowment practices in the Muslim and non-Muslim traditions.

\section{References}

Abdel Haleem, Muhammad. 2011. Understanding the Qur'an: Themes and Style. London: I.B. Tauris.

Abu Bakar, Alyasa 2003. Sharì'ah Islam di Provinsi NAD: Paradigma, Kebijakan dan Kegiatan, Banda Aceh: Dinas Syariat Islam NAD.

Abu al-Fajr, 1319. al-Sharh al-Kabīr 'alā Matan al-Mughnī. Kairo: Dar Amirah.

Aiz, Muhammad, 2017. Praktik Istibdāl Wakaf Saham pada Tabung Wakaf Indonesia. Jakarta: Cinta Buku Media.

Askari, Hossen, 2005. The Principle Foundation of an Islamic Economy, Banza Nazional del Lavaro, Quarterly Review, See http//e-resources.pepusnas.go.id/Library. Accessed on 19 Sept 2017.

Bowen, John R. Islam, Law and Equality in Indonesia: An Anthropology of Public Reasoning. Cambridge Univ. Press, 2003. Journal of Business and Management, Review Oman Chapter, Vol.3, No.9, April 2014.

Bukhari, Imam 1991. Șahih Bukhāri. Beirut: Dar Ihya Ulum Turats al-Arab.

Cormick, Neil Mac, 1978. Legal Reasoning and Legal Theory. Oxford: Clarendon Press.

Direktorat Pemberdayaan Wakaf dan Direktorat Jenderal Bimbingan Masyarakat Islam, 2008. Paradigma Baru Waqaf di Indonesia. Jakarta: Kemenag RI.

El-Awa, Salwaa, 2006. Textual Relations in the Qur'an: Relevance, Coherence and Structure. London \& New York: Routledge.

Fahruroji. 2015. Pengembangan Harta Benda Wakaf dengan Istibdāl: Studi Kasus Istibdāl Wakaf di Indonesia Tahun 2007-2012. Banten: LSIP.

Friedman, Lawrence M., 1975. The Legal System: A Social Science Perspective, New York: Russel Sage Foundation.

Friedman, W. 1953. Legal Theory, London: Stevens and SonsLtd.

Al-Ghazali, 1997. al-Mustasfā min Ilm al-Ușūl. Beirut: Dar al-Fikr.

Goldfeld, Yesyayahu, 1988. "The Development of Theory on Qur'anic Exegesis in Islamic Schoolarship," Studia Islamica.

Hanafi, Hassan. Hermeneutic, Liberation and Revolution, Cairo: Dar Kebaa Bookshop.

Hart, H.L.A., 1972 The Concept of Law, Oxford: Clarendon Press Oxford Univ, Press.

Hasan, Talhah, Agustus 2009. "Istibdāl dan Harta Benda Wakaf." al-Awqāf Jurnal Waqaf dan Ekonomi Islam, Vol.2, No.3.

al-Hasani al-Azhar, Basri Bin Ibrahim, 2011. "Maqāṣid al-Sharī'ah According to Qaradhawi in the Book al-Halāl wa al-Harām fi Islām." Internasional Jurnal of Business and Science, Vol. 2, No.1, Januari 2011. Debates on Legal Reasoning Throughout the Jurisprudence, The Journal of International Social Research, Vol.4, No. 1, April 2011.

Ibn Mandzur, 1996. Lisān al- 'Arab. Makkah al-Mukarromah: Dar al-Baz.

Ibrahim, Abu FadlMuhsin. Vaccination in the Context of Maqāssid al-Sharī'ah, Arabian

Ibrahim, Muhammad Bakri Bin. 2008. "Pelakasanaan Skim Wakaf Tunai oleh Yayasan Wakaf Malaysia," Jurnal Jawhar Vol.2, No.1, Januari.

Karic, Enes. "Interpretation of the Qur'an and the Destiny of the Islamic Word", Islamic Studies, Vol. 36 No 1. Spring: 1997.

Kohls, John. \& Christensen, Sandra L. 2002. The Business, Responsibility for Wealth Distribution in Globalized Political Economy, Journal of Business Ethics, Vol.2, 
No.3, Februari.

Lawrence, Bruce. 2006.The Qur'an: A Biograhy. New York: Atlantic Monthly Press.

Lewinstein, Keith. 1994. "Notes on Eastern Hanafie Heresiography", Journal of the American Oriental Society, Vol. 114 No.4.

Lowry, Joseph E. 2004. "The Legal Hermeneutics of al-Shafi'i and Ibn Qutayba: A Reconsideration", Islamic Law and Society, Vol. 11, No. 1.

McLeod, Ian. 1996. Legal Method. London: Macmillan Press Ltd.

Neuwith, Angelika, Nicolai Sinai and Michel Marx. 2010. The Qur'an in Context: Historical and Literary Investigations into the Qur'anic Milieu. Leiden \& Boston: Brill.

Rahman, Fazlur. 1970. "Islamic Modernism: Its Scope, Method and Alternatives", International Journal of Middle East Studies, Vol.I, No. 4.

al-Ra'yi, Hilal. 1335. Waqf al-Hilal. Kairo: Majlis Dairah al-Ma'arif al-Uthmaniyyah Haidar al-Dakhnu.

Reda, Nevin. 2010. "Holistic Approaches to the Qur'an: A Historucal Background". Religion Compass 4, No.8.

Rippin, Andrew. 2013. "Contemporary scholarly Understandings of Qur'anic Coherence". Al-Bayan, No.2.

Rippin, Andrew. 2009. The Blackwell Companion to the Qur'an. West Sussex: WileyBlackwell.

Saeed, Abdullah. 2008. "Some Reflection in the Contextualis Approach to Ethico-Legal Text of the Qur'an", Bulletin of the school of Oriental and Arfican Studies University of London, Vol. 71 No.2.

Al-Shatibi. 1997. al-Muwāfaqāt. Beirut Dar Ibnu Affan.

Shesthopalets, D. 2013. "Interpretation of the Term Muhkamat dan Mutasabihat in Medieval Qur'anic Exegesis," Journal of Qur'anic Studies.

Sulong, Jasmi B. 2014. "Permissibility of Istibdāl in Islamic Law and The Practice in Malaysia." Journal of US-China Public Administration, Vol.10, No.7, Desember.

Tim Penulis, 2008. Panduan Pemberdayaan Tanah Wakaf Produktif Strategis di Indonesia. Jakarta: Departemen Agama.

Undang-Undang Nomor 41 Tahun 2004 tentang Wakaf, chapter 40.

Undang-Undang Nomor 41 Tahun 2004 tentang Wakaf, chapter 41, article 1

Undang-Undang Nomor 41 Tahun 2004 tentang Wakaf, chapter 41, article 2

Volker, Katharina. 2011. "Qur'an and Reform: Rahman, Arkoun, Abu Zayd". Dessertation at the University of Otago.

Wahid, Marzuki. Fiqh Madhhab Negara atasPembacaan KHI. Jakarta:UNJ Press

Weiss, Bernard, 1978. "Interpratation in Islamic Law: The Teory of Ijtihad", The American Journal of Comparative Law, Vol. 26, No.2.

Wieland, Rotrand, 2002. "Exegesis of the Qur'an: Early Modern and Contemporary". In Encyclopedia of the Qur'an. Jane McAuliffe. Leiden-Boston: E.J Brill.

William, Wesley, 2002. "Aspect of the Creed of Imam Ahmad ibn Hambal: A Study of Anthropomorfism in Early Islamic Discourse", International of Middle East Studies, Vol. 34, No.3.

Wright, Peter Matthews, 2008. "Modern Qur'anic Hermeneutics". Dissertation at the University of North Carolina at Chapel Hill.

Zuhaily, Wahbah, 2008. al-Fiqh al-Islāmi wa Adillatuhu. Beirut: Dar al-Fikr. 